\title{
Performance of soybean plants as function of seed size: II. Nutritional stress ${ }^{1}$
}

\author{
Marcos Morais Soares²*, Glauter Lima Oliveira², Paulo Emídio Soriano², \\ Marcelo Coelho Sekita ${ }^{3}$, Tuneo Sediyama²
}

\begin{abstract}
The high quality seed is an input with invaluable for obtaining soybean crops with higher yields; for it reflects the results of high investments in research of modern technologies, which will be converted into high productivity levels. Thus, the aim of this study was assessing performance of soybean seeds, sorted by size, and grown in soils with different phosphorus levels. To this, seeds of two soybean cultivars (MSoy 9144RR and MSoy 8527RR) were sorted with aid of circular screens with perforations of $5.5 \mathrm{~mm}$ and $7.5 \mathrm{~mm}$ in diameter. Sowing was carried out into plastic pots, with $3.0 \mathrm{dm}^{3}$ substrate capacity each, containing a Red-Yellow Oxisol, fertilized with increasing phosphorus dosages (50, 100, 200, 300 and $400 \mathrm{mg}^{\mathrm{Kg}} \mathrm{Kg}^{-1}$ ), and performed under greenhouse environmental conditions. Seed size did not significantly influence the values obtained to the variables analyzed; however, to the larger seeds there was a trend of increase on these values. There was also a trend of increase on these values to all variables assessed when the dosages of phosphorus in the soil were increased.
\end{abstract}

Index terms: Glycine max, screen perforation size, vigor, phosphorus.

\section{Desempenho de plantas de soja em função do tamanho das sementes: II. Estresse nutricional}

\begin{abstract}
RESUMO - A alta qualidade da semente é um insumo com valor inestimável para a obtenção de lavouras de soja com altos rendimentos; pois reflete os resultados de altos investimentos em pesquisa de tecnologias modernas, que serão convertidas em elevados níveis de produtividade. Sendo assim, o objetivo deste estudo foi avaliar o desempenho de sementes de soja, classificadas por tamanho, e cultivadas em solos com diferentes níveis de fósforo. Para tanto, sementes de duas cultivares soja (MSoy 9144RR e MSoy 8527RR), foram classificadas em peneiras circulares de tamanho 14 e 18, com crivos de 5,5 e 7,5 $\mathrm{mm}$ de diâmetro. A semeadura foi feita em vasos plásticos, com capacidade para 3,0 $\mathrm{dm}^{3}$ de substrato, contendo Latossolo vermelho-amarelo, adubado com doses crescentes de fósforo (50, 100, 200, 300 e 400 mg.kg ${ }^{-1}$ ), e realizada sob condições ambientais de casa de vegetação. O tamanho das sementes não influenciou significativamente os valores obtidos para as variáveis analisadas; porém houve tendência de incremento desses valores nas sementes maiores. Com o aumento das doses de fósforo no solo também houve tendência de aumento nos valores obtidos para todas as variáveis analisadas.
\end{abstract}

Termos para indexação: Glycine max, diâmetro de crivo, vigor, fósforo.

\section{Introduction}

Among the grain-producing crop species grown in Brazil, soybean (Glycine max (L.) Merr.) is considered one of the crops with the most economical potential for internal and external marketing (Avila et al., 2008).

On an economically viable soybean production process, the adoption of advanced seeding techniques, or the use of modern cropping systems are not sufficient, once the quality of the seeds to be used in the sowing is considered as the

${ }^{1}$ Submitted on 11/23/2012. Accepted for publication on 05/07/2013. ${ }^{2}$ Departamento de Fitotecnia, UFV, 36570-000 - Viçosa, MG, Brasil. major factor to the establishment of the crop in the field, as well as to the adequate development of the soybean plants on the cropped area. Low quality seeds generally have the vigor and germination reduced; thereby yielding non-uniform crops, and crop fields with low plant population (Scheeren et al., 2010). According to Rezende et al. (2003) the high productivity of a crop depends on the quality of the seeds used for the sowing, since the performance of these seeds is directly related to the historic of its production, of its processing, and of soil conditions on which such crop will be established.

${ }^{3}$ Departamento de Fisiologia Vegetal, UFV, 36570-000 - Viçosa, MG, Brasil *Corresponding author<agromms@yahoo.com.br> 
The use of seeds with low vigor or low physiological potential may indirectly influence crop productivity by affecting the rate of seed germination, the emergence percentage of seedlings, and the final stand of seedlings in the field; or directly through the negative influence on plant vigor. Therefore, the low seed vigor has been associated to reductions on speed of seed germination, to uneven emergence of seedlings, to reduced height of plants, to lower dry matter production, to reduction on leaf area, growth rates, and crop productivity (Marcos-Filho, 2005). The quality of seeds has also been routinely attributed to their physical, physiological, sanitary, and genetic qualities (Carvalho and Nakagawa, 2012). In addition to these attributes, the uniformity of seed size until today generates controversies regarding issues of economics on the grain production process, and on productive performance of soybean.

Thus, the main reason to sort the soybean seeds by size comes from the current technological demand of the sowing process, in which the soybean plant population of new cultivars in the field was reduced to 200,000 to 300,000 plants. $^{-1}$, aiming at obtaining higher yields due to smaller plant lodging. Therefore, errors on sowing density, which might endanger the crop installation in the field, and consequently all investment losses to them aggregated, are not allowed.

Studies related to corn and soybean seeds have shown that the weight and size of the seeds did not influence the results of tests conducted in the laboratory, and also did not affect the performance of plants in the field (Avila et al., 2008; Fonseca and Sá, 2005; Lima and Carmona, 1999; Perin et al., 2002; Piccinin et al., 2012). However, Pádua et al. (2010) and Santos et al. (2005), have obtained increase in the soybean yield with plants originating from larger size seeds.

Besides the influence of seed size on yield, the level of soil fertility is of fundamental importance for the seeds are able to express all their potential vigor, which may influence crop productivity. Among the nutrients, phosphorus $(\mathrm{P})$ is of fundamental importance to the soybean crop, as it participates in various metabolic processes, such as the transfer of energy (ATP), photosynthesis, respiration, synthesis of nucleic acids and glucose, synthesis and stability of the cell membranes (phospholipids), activation and deactivation of enzymes (Vance et al., 2003), besides being very important in the biological nitrogen fixation.

Although, in some of these studies, the seed vigor had been correlated to the seed size, the influence of this factor on the best establishment of the plants in the field, which may be reflected in the yield, it is not a completely understood subject, especially under certain stress conditions, as in case of the nutritional deficiency, on which only little results have been reported in the literature.

In face of the foregoing, the aim of this study was investigating the effect of seed size on yield components of the soybean crop, grown in soils containing different levels of phosphorus availability.

\section{Material and Methods}

The experiment was carried out under greenhouse environmental conditions and in the Seed Research Laboratory of Federal University of Viçosa (UFV), headquartered in the municipality of Viçosa, state of Minas Gerais, Southeast Region of Brazil. To this, the seeds of two transgenic soybean cultivars (MSoy 9144RR and MSoy 8527RR), sorted in two different sizes, were used in the experiment. The seed sorting was performed by using circular screens, with perforations sizes of $5.5 \mathrm{~mm}$ and 7.5 $\mathrm{mm}$, corresponding to screens of number 14 and 18, respectively.

Before establishing the experiment, the seeds were treated with fungicide, as well as with biological inoculant. These two treatments were applied at the following sequence: firstly, the seeds were treated with the fungicide Derosal Plus ${ }^{\circledR}$ (carbendazim + thiram) at a dosage of $200 \mathrm{~mL} .100 \mathrm{~kg}^{-1}$ seed, and then left to stand for about $10 \mathrm{~min}$., for drying and fixation of fungicide. Immediately after, a peat inoculant, containing the nitrogen-fixing bacterium Bradyrhizobium japonicum was applied at a dosage of 3,0 million bacterial cells per seed (Embrapa, 2011; Sediyama, 2009). After treatments, seeds were sown into plastic pots, with capacity of $3.0 \mathrm{dm}^{3}$ of soil each. The soil used in the experiment was a Red-Yellow Oxisol, originating from a still non-cultivated area.

Chemical and physical analyses of soil were also performed before experiment installation. Phosphorus fertilization was applied before sowing, so as to obtain five different levels of this element in the soil (50, 100, 200, 300, and $400 \mathrm{mg} \cdot \mathrm{kg}^{-1}$ soil), by using the triple superphosphate as source of that macroelement. Potassium fertilization was also performed before sowing. However, topdressing fertilization with micronutrients was performed at 15 days after seedling emergence. The dosages of the other nutrients were determined according to soil analysis recommendations.

Into each of the plastic pots were sown four soybean seeds, which were equidistantly distributed from each other, at a depth of $3.0 \mathrm{~cm}$. After emergence, only the two more vigorous seedlings were maintained in each pot. Whenever needed, irrigation was carried out with deionized water in order to maintain the water content in soil at circa $2 / 3$ of the field capacity (Novais et al., 1991).

Harvest was performed at 15 days after the plants reached the reproductive stage $\mathrm{R} 8$, which is characterized by more than $95 \%$ mature pods per plant (Sediyama, 2009). After harvest, the following assessments were carried out: 
Yield components: the number of pods per plant, number of seeds per pod, number of seeds per plant, 100 seed mass, and total mass of seeds per plant were assessed; thus obtaining the yield of each treatment. To compute productivity, the seed moisture content was determined by the standard oven method, at $105 \pm$ $3{ }^{\circ} \mathrm{C}$, for $24 \mathrm{~h}$ (Brasil, 2009), which was then corrected to $14 \%$.

Plant height and number of nodes: was carried out with the aid of a ruler graduated in centimeters, by measuring height of each plant from the base until its apex; and results were expressed in $\mathrm{cm}$. At each of the plant height assessments, the counting of node numbers per plant was also performed.

Height of first pod insertion: this determination was also carried out with the aid of a ruler graduated in centimeters, and performed by measuring the distance from the plant base until the height of first pod insertion; and results were also expressed in centimeters.

The experiment was carried out in a randomized block experimental design with five replications, and with treatments arranged in a factorial design 2 × 2 × 5 [2 soybean cultivars (MSoy 9144RR and MSoy 8527RR) x 2 seed sizes, sorted by screening (screen number 14 (perforation diameter of $5.5 \mathrm{~mm}$ ), and screen number 18 (perforation diameter of $7.5 \mathrm{~mm}$ ) x 5 phosphorus dosages in the soil $\left(50,100,200,300\right.$ and $\left.\left.400 \mathrm{mg} \cdot \mathrm{kg}^{-1}\right)\right]$, what resulted in 20 treatments. Data were subjected to exploratory analyzes to assess the assumptions of normality of residuals, homogeneity of variance of treatments, and additivity of the model, to allow applying the ANOVA. The mean values obtained for seed size were compared by $F$ test $(\mathrm{p}<0.05)$, and the mean values obtained for yield components were subjected to regression analysis. All data were computed by using the SAS software (Delwiche and Slaughter, 2003).

\section{Results and Discussion}

The mean values obtained for plant height are presented on Table 1. For the soybean cv. MSoy 9144RR, statistically significant differences for this parameter were found only at the dose of $50 \mathrm{mg} \cdot \mathrm{kg}^{-1} \mathrm{P}$ in the soil, in which the smaller seeds have also produced smaller plants. However, for the other dosages of $\mathrm{P}$ in the soil, the differences among values obtained for plant height were not statistically significant. On Figure 1 it is also possible observing a growing increase on height of plants with the increase on dosages of phosphorus in the soil, for both soybean cultivars used in the study. On observing the effect of seed size on productivity and physiological quality of soybean seeds, Pádua et al. (2010) have also found that there was no statistically significant differences among plant height values when the comparison was performed only between plants originating from larger seeds $(5.0 \mathrm{~mm}$ and $6.0 \mathrm{~mm})$.
Table 1. Mean values obtained for height of soybean plants (cm) originating from seeds of two soybean cultivars, classified by screens with perforations of two sizes, and grown into plastic pots containing soil with different dosages of phosphorus (P), under greenhouse environmental conditions.

\begin{tabular}{|c|c|c|c|c|c|}
\hline \multirow{3}{*}{$\begin{array}{l}\text { Perforation } \\
\text { diameter }\end{array}$} & \multicolumn{5}{|c|}{ Dosage of $\mathrm{P}$ in the soil $\left(\mathrm{mg} \cdot \mathrm{kg}^{-1}\right)$} \\
\hline & 50 & 100 & 200 & 300 & 400 \\
\hline & \multicolumn{5}{|c|}{ Cv. MSoy 9144RR } \\
\hline $5.5 \mathrm{~mm}$ & $68.2 b^{*}$ & $97.2 \mathrm{a}$ & $101.5 \mathrm{a}$ & $155.4 \mathrm{a}$ & $151.4 \mathrm{a}$ \\
\hline $7.5 \mathrm{~mm}$ & $90.3 \mathrm{a}$ & $90.1 \mathrm{a}$ & $116.1 \mathrm{a}$ & $156.4 \mathrm{a}$ & $161.9 \mathrm{a}$ \\
\hline CV $(\%)$ & \multicolumn{5}{|c|}{13.18} \\
\hline $\begin{array}{l}\text { Perforation } \\
\text { diameter }\end{array}$ & \multicolumn{5}{|c|}{ Cv. MSoy 8527RR } \\
\hline $5.5 \mathrm{~mm}$ & $67.2 \mathrm{a}^{*}$ & $75.3 \mathrm{a}$ & $86.8 \mathrm{a}$ & $90.9 \mathrm{a}$ & $117.2 \mathrm{a}$ \\
\hline $7.5 \mathrm{~mm}$ & $65.7 \mathrm{a}$ & $77.8 \mathrm{a}$ & $94.3 \mathrm{a}$ & 99.9 a & $111.5 \mathrm{a}$ \\
\hline CV $(\%)$ & \multicolumn{5}{|c|}{11.69} \\
\hline
\end{tabular}

*Means followed by the same letter, within each dose of $\mathrm{P}$, do not statistically differ between each other by $\mathrm{F}$ test $(\mathrm{P}<0.05)$; $\mathrm{CV}=$ Coefficient of variation.
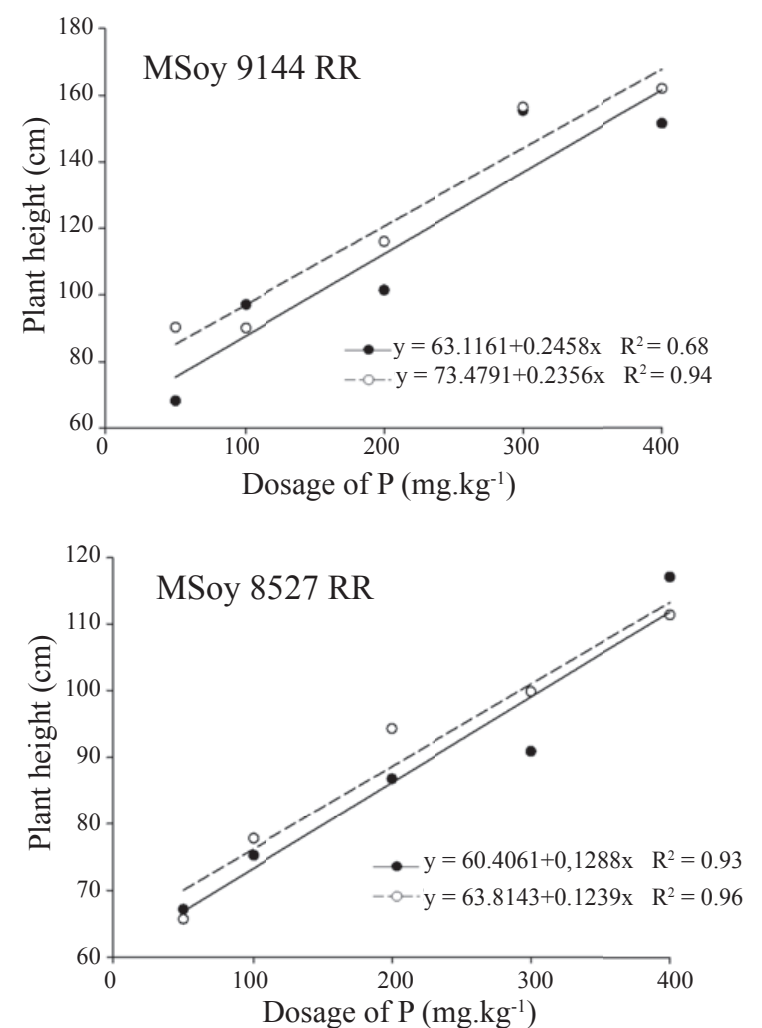

Figure 1. Graphical representation of the linear regression curves plotted with the mean values obtained to height of soybean plants originated from seeds of two soybean cultivars, classified by screens with two perforation sizes, and grown into plastic pots containing soil with different dosages of phosphorus (P), under greenhouse environmental conditions. 
According to Kolchinski et al. (2006) and Munizzi et al. (2010), high vigor seeds generally present a faster metabolic processes; thus enabling the faster and uniform emission of the primary root during the germination process, as well as a higher growth rate, thus producing plants with larger size at the initial development stages.

From data presented on Table 2, it may be verified that the seed size did not influence the first pod insertion for both the cultivars assessed. However, for the cultivar MSoy 9144RR, there was a linear increase of this characteristic with the increasing phosphorus availability in the soil (Figure 2). According to Finoto et al. (2011), the height of the first pod insertion is the most important factor on carrying out the soybean mechanized harvesting. Therefore, for that such cultural practice is economically viable, it is recommended that the cultivar used in the sowing holds the genes for the first pod insertion) between $10 \mathrm{~cm}$ and $20 \mathrm{~cm}$ in height.

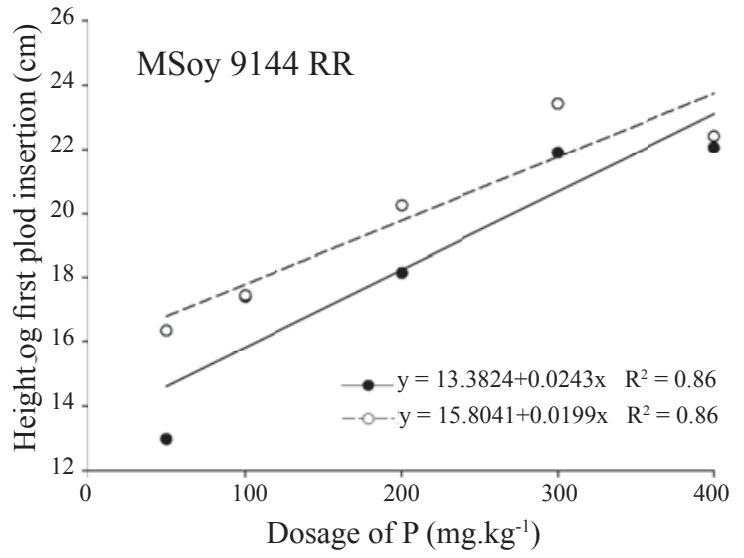

Figure 2. Graphical representation of the linear regression curves plotted with the mean values obtained to height of first pod insertion of soybean plants originated from seeds of two soybean cultivars, classified by screens with two perforation sizes, and grown into plastic pots containing soil with different dosages of phosphorus (P), under greenhouse environmental conditions.

Concerning the number of nodes per plant, the linear regression curves presented on Figure 3 show that, when phosphorus levels in the soil were increased, there was also an increase on the number of nodes per plant; which, for both cultivars assessed have ranged from 12 to 17 per plant. To both cultivars assessed, there was no statistically significant difference between the values obtained to this morphological characteristic for the plants originated from seeds of both sizes; except for cultivar MSoy 9144RR, at the dosage of 100 mg.kg-1 phosphorus in the soil, for the seeds sorted by the screen 14, with perforations of $5.5 \mathrm{~mm}$ in diameter (Table 3 ).

Through the linear regression curves, plotted with the mean

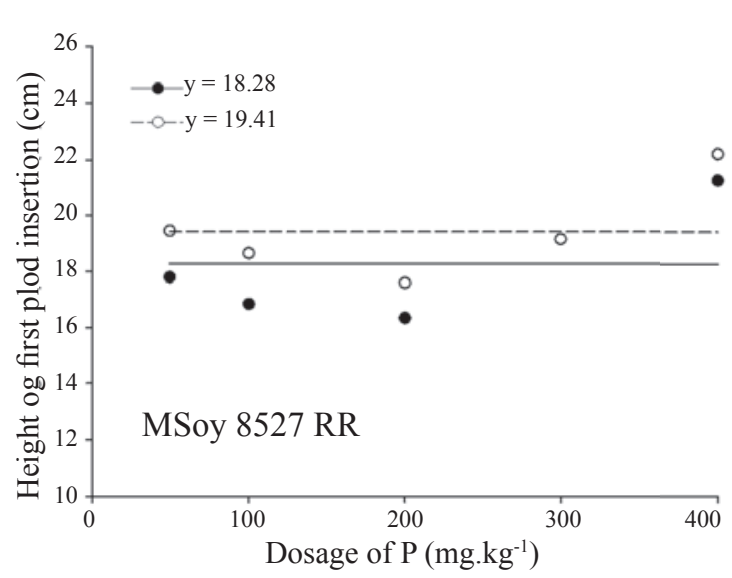

Table 2. Mean values obtained for height of first pod insertion (cm) on soybean plants originating from seeds of two soybean cultivars, classified by screens with two perforation sizes, and grown into plastic pots containing soil with different dosages of phosphorus (P), under greenhouse environmental conditions.

\begin{tabular}{|c|c|c|c|c|c|}
\hline \multirow{3}{*}{$\begin{array}{l}\text { Perforation } \\
\text { diameter }\end{array}$} & \multicolumn{5}{|c|}{ Dosage of P in the soil (mg. $\left.\mathrm{kg}^{-1}\right)$} \\
\hline & 50 & 100 & 200 & 300 & 400 \\
\hline & \multicolumn{5}{|c|}{ Cv. MSoy 9144RR } \\
\hline $5.5 \mathrm{~mm}$ & $13.0 \mathrm{a}^{*}$ & $17.4 \mathrm{a}$ & $18.2 \mathrm{a}$ & $21.9 \mathrm{a}$ & $22.1 \mathrm{a}$ \\
\hline $7.5 \mathrm{~mm}$ & $16.4 \mathrm{a}$ & $17.5 \mathrm{a}$ & $20.3 \mathrm{a}$ & $23.4 \mathrm{a}$ & $22.4 \mathrm{a}$ \\
\hline $\mathrm{CV}(\%)$ & \multicolumn{5}{|c|}{17.59} \\
\hline $\begin{array}{c}\text { Perforation } \\
\text { diameter }\end{array}$ & \multicolumn{5}{|c|}{ Cv. MSoy 8527RR } \\
\hline $5.5 \mathrm{~mm}$ & $17.8 \mathrm{a}^{*}$ & $16.9 \mathrm{a}$ & $16.4 \mathrm{a}$ & $19.2 \mathrm{a}$ & $21.3 \mathrm{a}$ \\
\hline $7.5 \mathrm{~mm}$ & $19.5 \mathrm{a}$ & $18.7 \mathrm{a}$ & $17.6 \mathrm{a}$ & $19.2 \mathrm{a}$ & $22.2 \mathrm{a}$ \\
\hline CV (\%) & \multicolumn{5}{|c|}{18.12} \\
\hline
\end{tabular}

* Means followed by the same letter within each dose of $\mathrm{P}$, do not statistically differ between each other by $\mathrm{F}$ test $(\mathrm{P}<0.05) ; \mathrm{CV}=$ Coefficient of variation 
Table 3. Mean values obtained for the number of nodes per soybean plants originating from seeds of two soybean cultivars, classified by screens with two perforation sizes, and grown into plastic pots containing soil with different dosages of phosphorus (P), under greenhouse environmental conditions.

\begin{tabular}{|c|c|c|c|c|c|}
\hline \multirow{3}{*}{$\begin{array}{l}\text { Perforation } \\
\text { diameter }\end{array}$} & \multicolumn{5}{|c|}{ Dosage of $\mathrm{P}$ in the soil $\left(\mathrm{mg} \cdot \mathrm{kg}^{-1}\right)$} \\
\hline & 50 & 100 & 200 & 300 & 400 \\
\hline & \multicolumn{5}{|c|}{ Cv. MSoy 9144RR } \\
\hline $5.5 \mathrm{~mm}$ & $11.80 \mathrm{a}^{*}$ & $13.30 \mathrm{a}$ & $14.20 \mathrm{a}$ & $16.70 \mathrm{a}$ & $16.00 \mathrm{a}$ \\
\hline $7.5 \mathrm{~mm}$ & $12.00 \mathrm{a}$ & $12.20 \mathrm{~b}$ & $13.90 \mathrm{a}$ & $15.63 \mathrm{a}$ & $17.30 \mathrm{a}$ \\
\hline $\mathrm{CV}(\%)$ & \multicolumn{5}{|c|}{6.71} \\
\hline $\begin{array}{c}\text { Perforation } \\
\text { diameter }\end{array}$ & \multicolumn{5}{|c|}{ Cv. MSoy 8527RR } \\
\hline $5.5 \mathrm{~mm}$ & $11.90 \mathrm{a}^{*}$ & $13.60 \mathrm{a}$ & $14.80 \mathrm{a}$ & $16.10 \mathrm{a}$ & $16.80 \mathrm{a}$ \\
\hline $7.5 \mathrm{~mm}$ & $12.70 \mathrm{a}$ & $13.40 \mathrm{a}$ & $14.70 \mathrm{a}$ & $16.20 \mathrm{a}$ & $17.38 \mathrm{a}$ \\
\hline CV (\%) & \multicolumn{5}{|c|}{5.22} \\
\hline
\end{tabular}

*Means followed by the same letter within each dose of $\mathrm{P}$, do not statistically differ between each other by $\mathrm{F}$ test $(\mathrm{P}<0.05)$; $\mathrm{CV}=$ Coefficient of variation.
Table 4. Mean values obtained for the number of pods per soybean plants originating from seeds of two soybean cultivars, classified by screens with two perforation sizes, and grown into plastic pots containing soil with different dosages of phosphorus (P), under greenhouse environmental conditions.

\begin{tabular}{|c|c|c|c|c|c|}
\hline \multirow{3}{*}{$\begin{array}{c}\text { Perforation } \\
\text { diameter }\end{array}$} & \multicolumn{5}{|c|}{ Dosage of $\mathrm{P}$ in the soil $\left(\mathrm{mg} \cdot \mathrm{kg}^{-1}\right)$} \\
\hline & 50 & 100 & 200 & 300 & 400 \\
\hline & \multicolumn{5}{|c|}{ Cv. MSoy 9144RR } \\
\hline $5.5 \mathrm{~mm}$ & $14.00 a^{*}$ & $18.90 \mathrm{a}$ & $24.40 \mathrm{~b}$ & $45.70 \mathrm{a}$ & $47.50 \mathrm{a}$ \\
\hline $7.5 \mathrm{~mm}$ & $15.50 \mathrm{a}$ & $20.80 \mathrm{a}$ & $31.60 \mathrm{a}$ & $41.75 \mathrm{a}$ & $47.00 \mathrm{a}$ \\
\hline CV (\%) & \multicolumn{5}{|c|}{14.41} \\
\hline $\begin{array}{l}\text { Perforation } \\
\text { diameter }\end{array}$ & \multicolumn{5}{|c|}{ Cv. MSoy 8527RR } \\
\hline $5.5 \mathrm{~mm}$ & $16.10 \mathrm{a}$ & $28.60 \mathrm{a}$ & $34.30 \mathrm{a}$ & $55.70 \mathrm{a}$ & $55.80 \mathrm{a}$ \\
\hline $7.5 \mathrm{~mm}$ & $20.00 \mathrm{a}$ & $26.60 \mathrm{a}$ & $35.80 \mathrm{a}$ & $53.80 \mathrm{a}$ & $58.50 \mathrm{a}$ \\
\hline CV $(\%)$ & \multicolumn{5}{|c|}{10.13} \\
\hline
\end{tabular}

*Means followed by the same letter, within each dose of $\mathrm{P}$, do not statistically differ between each other by $\mathrm{F}$ test $(\mathrm{P}<0.05)$; $\mathrm{CV}=$ Coefficient of variation.
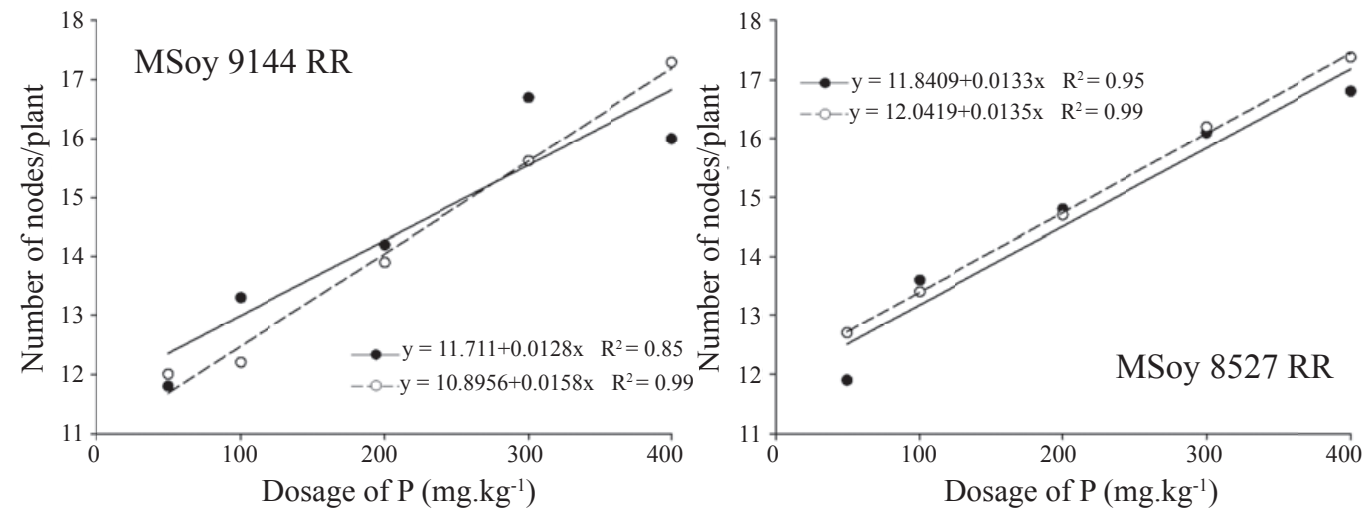

Figure 3. Graphical representation of the linear regression curves plotted with the mean values obtained for the number of nodes per soybean plants originated from seeds of two soybean cultivars, classified by screens with two perforation sizes, and grown into plastic pots containing soil with different dosages of phosphorus $(\mathrm{P})$, under greenhouse environmental conditions.
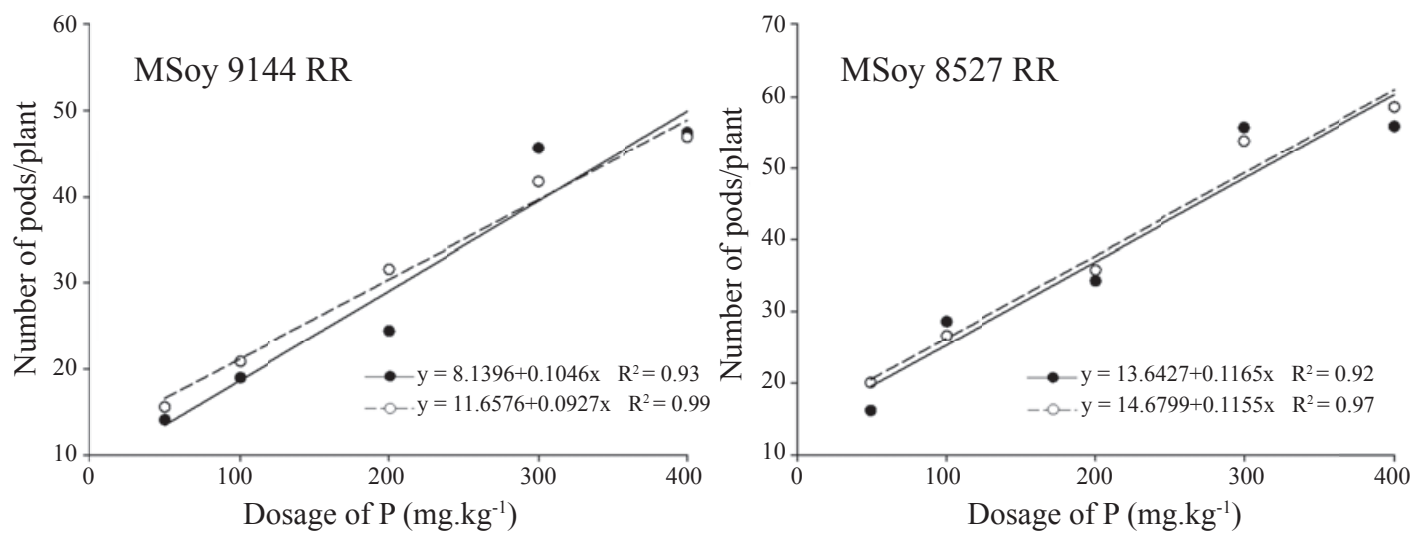

Figure 4. Graphical representation of the linear regression curves plotted with the mean values obtained for the number of pods per soybean plants originated from seeds of two soybean cultivars, classified by screens with two perforation sizes, and grown into plastic pots containing soil with different dosages of phosphorus $(\mathrm{P})$, under greenhouse environmental conditions. 
Regardless the size of seeds used in this study, differences between values obtained for number of seeds per pod were not statistically significant, for both cultivars assessed (Table 5). Only the larger seeds of the soybean cultivar MSoy 8527RR have shown a linear increase to this trait with the application of increasing phosphorus dosages in the soil (Figure 5). On studies carried out on the performance of soybean cultivars, as a function of seed size, Camozzato et al. (2009) have found similar results. Likewise, Piccinin et al. (2012), by studying the relationship between the size and physiological and health quality of soybean seeds have also found no statistically significant differences between results obtained to this parameter.

Table 5. Mean values obtained for the number of seeds per pods produced by soybean plants originating from seeds of two soybean cultivars, classified by screens with two perforation sizes, and grown into plastic pots containing soil with different dosages of phosphorus (P), under greenhouse environmental conditions.

\begin{tabular}{|c|c|c|c|c|c|}
\hline \multirow{3}{*}{$\begin{array}{c}\text { Perforation } \\
\text { diameter }\end{array}$} & \multicolumn{5}{|c|}{ Dosage of $\mathrm{P}$ in the soil $\left(\mathrm{mg} \cdot \mathrm{kg}^{-1}\right)$} \\
\hline & 50 & 100 & 200 & 300 & 400 \\
\hline & \multicolumn{5}{|c|}{ Cv. MSoy 9144RR } \\
\hline $5.5 \mathrm{~mm}$ & $2.05 \mathrm{a}^{*}$ & $2.20 \mathrm{a}$ & $2.20 \mathrm{a}$ & $2.15 \mathrm{a}$ & $2.10 \mathrm{a}$ \\
\hline $7.5 \mathrm{~mm}$ & $2.16 \mathrm{a}$ & $2.23 \mathrm{a}$ & $2.29 \mathrm{a}$ & $2.21 \mathrm{a}$ & $2.16 \mathrm{a}$ \\
\hline CV $(\%)$ & \multicolumn{5}{|c|}{103.28} \\
\hline $\begin{array}{c}\text { Perforation } \\
\text { diameter }\end{array}$ & \multicolumn{5}{|c|}{ Cv. MSoy 8527RR } \\
\hline $5.5 \mathrm{~mm}$ & $1.83 \mathrm{a}$ & $1.93 \mathrm{a}$ & $1.90 \mathrm{a}$ & $1.87 \mathrm{a}$ & $2.01 \mathrm{a}$ \\
\hline $7.5 \mathrm{~mm}$ & $1.88 \mathrm{a}$ & $1.97 \mathrm{a}$ & $1.93 \mathrm{a}$ & $1.94 \mathrm{a}$ & $2.12 \mathrm{a}$ \\
\hline CV $(\%)$ & \multicolumn{5}{|c|}{89.34} \\
\hline
\end{tabular}

* Means followed by the same letter, within each dose of $\mathrm{P}$, do not statistically differ between each other by $\mathrm{F}$ test $(\mathrm{P}<0.05)$; $\mathrm{CV}=$ Coefficient of variation.

In a general way, through the linear regression curves, plotted to mean values obtained for the parameter number of seeds per plant, it may be observed that there was a homogenous and gradual increase, to the extent that the soil phosphorus dosages were increased to both cultivars assessed; even though without statistically significant differences among the mean values obtained to this parameter, when plants were originated from larger seeds $(7.5 \mathrm{~mm}$ diameter $)$ (Figure 6). Nevertheless, when plants were originated from smaller seeds (5.5 $\mathrm{mm}$ in diameter) (Table 6), it is also possible verifying that there was an increase in the number of seeds per plant, with statistically significant differences for cultivar MSoy $8527 \mathrm{RR}$, only at the dosages of 50 and $400 \mathrm{mg} \cdot \mathrm{kg}^{-1}$ phosphorus in the soil, and only at the dosage of $200 \mathrm{mg} \cdot \mathrm{kg}^{-1} \mathrm{P}$, for cultivar MSoy 9144RR. Such results demonstrate that the plants originating from larger seeds have
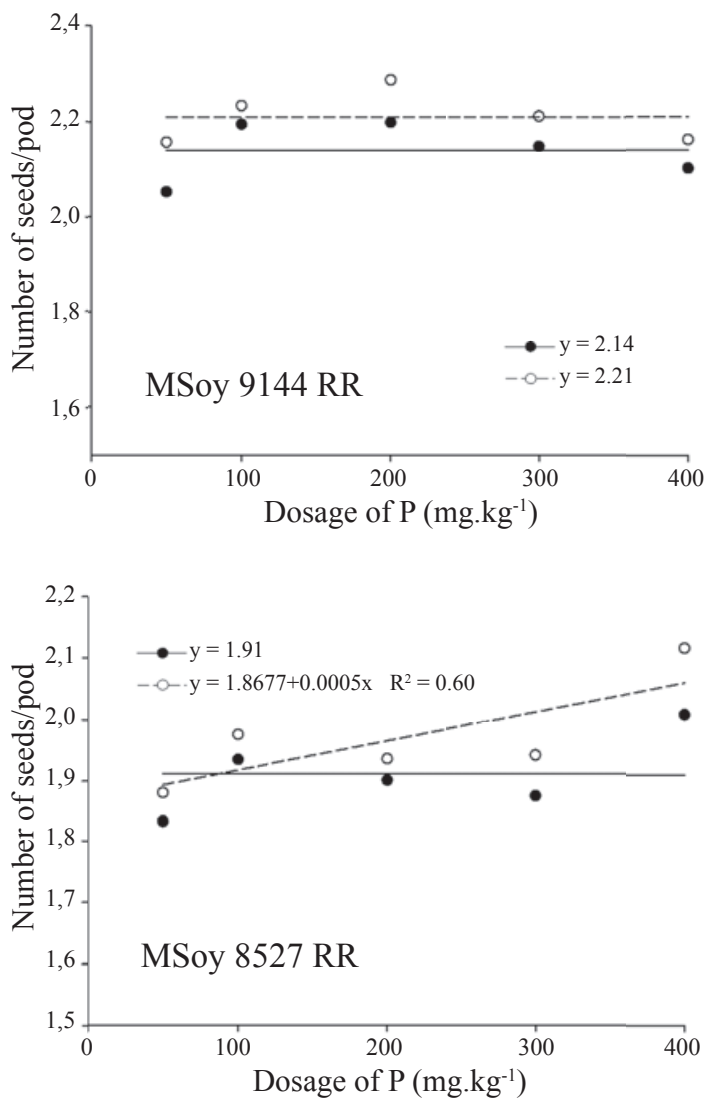

Figure 5. Graphical representation of the linear regression curves plotted with the mean values obtained for the number of seeds per pod produced by soybean plants originated from seeds of two soybean cultivars, classified by screens with two perforation sizes, and grown into plastic pots containing soil with different dosages of phosphorus (P), under greenhouse environmental conditions.

the trend of producing larger number of seeds per plant; what certainly will be reflected on soybean productivity.

On examining the mean values obtained for the mass of 100 seeds, shown on Figure 7, it can be noticed that, in general, to the extent that the dosage of soil phosphorus was increased, the mass of 100 seeds has also increased, for the two assessed seed sizes $(5.5 \mathrm{~mm}$ and $7.5 \mathrm{~mm})$. However, for cultivar MSoy 9144RR, the differences among mean values obtained for this variable were statistically lower for the larger seeds $(7.5 \mathrm{~mm})$ only at the dosage of $200 \mathrm{mg} \cdot \mathrm{kg}^{-1}$ phosphorus in the soil. Nevertheless, to cultivar MSoy 8527RR, this difference between the mean values obtained for the smaller seeds $(5.5 \mathrm{~mm})$ was significantly lower only at the dosage of $100 \mathrm{mg} \cdot \mathrm{kg}^{-1}$ phosphorus in soil (Table 7). Thereby, it is possible to infer that the larger seeds respond better to fertilization; besides allowing production of heavier seeds. 
Table 6. Mean values obtained for the number of seeds per plant, produced by soybean plants originating from seeds two soybean cultivars, classified by screens with two perforation sizes, and grown into plastic pots containing soil with different dosages of phosphorus (P), under greenhouse environmental conditions.

\begin{tabular}{|c|c|c|c|c|c|}
\hline \multirow{3}{*}{$\begin{array}{c}\text { Perforation } \\
\text { diameter }\end{array}$} & \multicolumn{5}{|c|}{ Dosage of $\mathrm{P}$ in the soil $\left(\mathrm{mg} \cdot \mathrm{kg}^{-1}\right)$} \\
\hline & 50 & 100 & 200 & 300 & 400 \\
\hline & \multicolumn{5}{|c|}{ Cv. MSoy 9144RR } \\
\hline $5.5 \mathrm{~mm}$ & $28.50 \mathrm{a}^{*}$ & $41.30 \mathrm{a}$ & $53.60 \mathrm{~b}$ & $97.90 \mathrm{a}$ & $99.75 \mathrm{a}$ \\
\hline $7.5 \mathrm{~mm}$ & $33.10 \mathrm{a}$ & $46.60 \mathrm{a}$ & $72.20 \mathrm{a}$ & $91.00 \mathrm{a}$ & $101.40 \mathrm{a}$ \\
\hline CV $(\%)$ & \multicolumn{5}{|c|}{7.57} \\
\hline $\begin{array}{c}\text { Perforation } \\
\text { diameter }\end{array}$ & \multicolumn{5}{|c|}{ Cv. MSoy 8527RR } \\
\hline $5.5 \mathrm{~mm}$ & $29.40 \mathrm{~b}$ & $55.30 \mathrm{a}$ & $65.20 \mathrm{a}$ & $104.20 \mathrm{a}$ & $115.20 \mathrm{~b}$ \\
\hline $7.5 \mathrm{~mm}$ & $37.40 \mathrm{a}$ & $52.30 \mathrm{a}$ & $69.30 \mathrm{a}$ & $104.30 \mathrm{a}$ & $123.75 \mathrm{a}$ \\
\hline CV (\%) & \multicolumn{5}{|c|}{5.20} \\
\hline
\end{tabular}

*Means followed by the same letter, within each dose of $\mathrm{P}$, do not statistically differ between each other by $\mathrm{F}$ test $(\mathrm{P}<0.05)$; $\mathrm{CV}=$ Coefficient of variation.
Table 7. Mean values obtained for the mass of 100 seeds (g), produced by soybean plants originating from seeds of two soybean cultivars, classified by screens with two perforation sizes, and grown into plastic pots containing soil with different dosages of phosphorus (P), under greenhouse environmental conditions.

\begin{tabular}{cccccc}
\hline \multirow{2}{*}{$\begin{array}{c}\text { Perforation } \\
\text { diameter }\end{array}$} & 50 & \multicolumn{5}{c}{ Dosage of P in the soil $\left(\mathrm{mg}^{\mathrm{k}} \mathrm{kg}^{-1}\right)$} \\
\cline { 2 - 5 } & \multicolumn{5}{c}{ Cv. MSoy 9144RR } \\
\hline $5.5 \mathrm{~mm}$ & $14.46 \mathrm{a}^{*}$ & $15.26 \mathrm{a}$ & $18.35 \mathrm{a}$ & $16.02 \mathrm{a}$ & $17.69 \mathrm{a}$ \\
$7.5 \mathrm{~mm}$ & $15.83 \mathrm{a}$ & $16.56 \mathrm{a}$ & $14.63 \mathrm{~b}$ & $17.32 \mathrm{a}$ & $17.31 \mathrm{a}$ \\
\hline $\mathrm{CV}(\%)$ & \multicolumn{5}{c}{9.18} \\
\hline Perforation \\
diameter
\end{tabular}

*Means followed by the same letter, within each dose of $\mathrm{P}$, do not statistically differ between each other by $\mathrm{F}$ test $(\mathrm{P}<0.05)$; $\mathrm{CV}=$ Coefficient of variation.
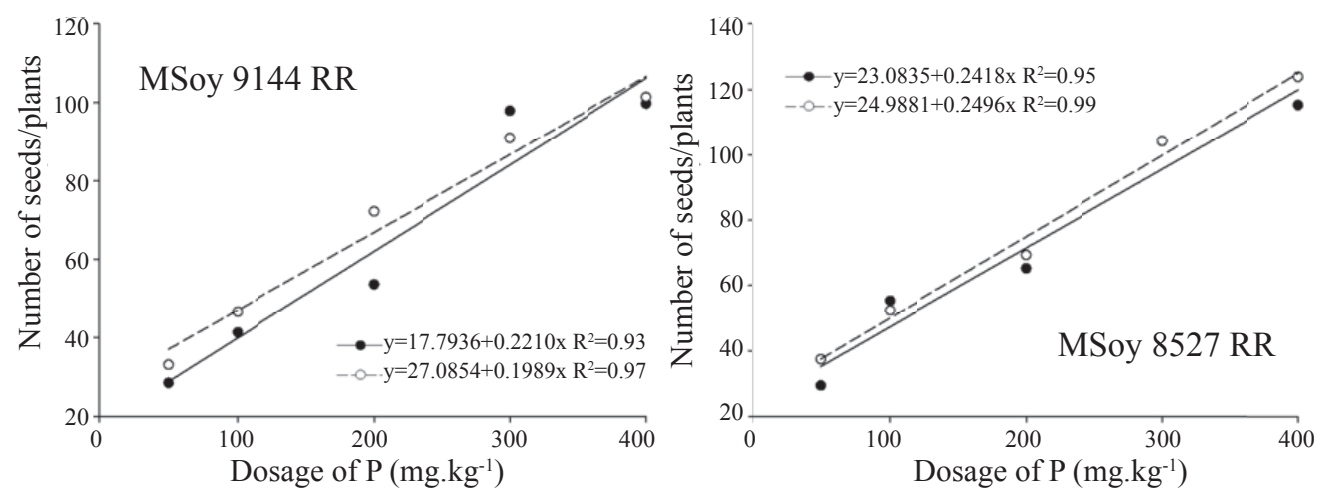

Figure 6. Graphical representation of the linear regression curves plotted with the mean values obtained for the number of seeds per plant, produced by soybean plants originated from seeds of two soybean cultivars, classified by screens with two perforation sizes, and grown into plastic pots containing soil with different dosages of phosphorus (P), under greenhouse environmental conditions.
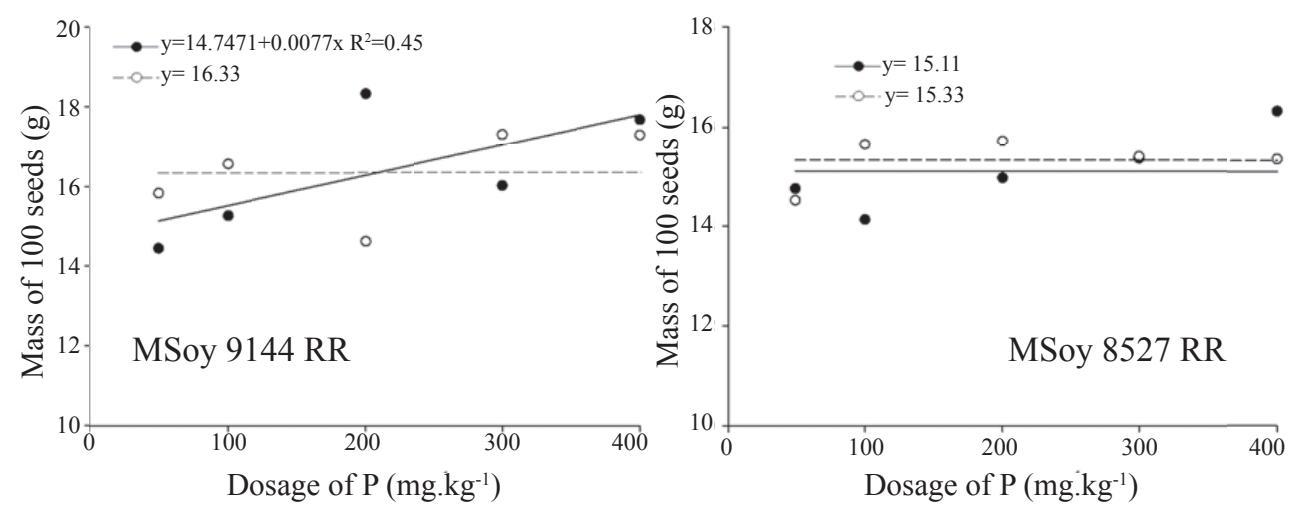

Figure 7. Graphical representation of the linear regression curves plotted with the mean values obtained for the mass of 100 seeds (g), produced by soybean plants originated from seeds of two different cultivars (MSoy 9144RR and MSoy $8527 R R$ ), classified by screens with two different perforations sizes, and grown into plastic pots containing soil with different dosages of phosphorus (P), under greenhouse environmental conditions. 
However, according to Ávila et al. (2008), the plants originating from small seeds are able to compensate their lesser initial growth at the later stages of the crop cycle; thus ensuring a production of grains similar to that of the plants originating from large seeds.

Nevertheless, Lima and Carmona (1999) in a study conducted with seeds of four different soybean cultivars, also classified by size, have found no statistically significant differences for the mass of grains produced by the plants originating from seeds of different sizes used in their study. In addition, these authors have also emphasized that selection of seeds by size classes is of phenotypic nature, and do not cause differences on productivity within the same soybean genotype solely as function of the different seed sizes used in the sowing.

By the linear regression curves shown on Figure 8, it can be verified that, to the extent that phosphorus dosages in the soil were increased there was also a positive linear increase in the values obtained for the total mass of seeds per plant for both soybean cultivars assessed. However, by the mean values obtained for the smaller size seeds ( $5.5 \mathrm{~mm}$ ), shown on Table 8 , it is also possible to verify that, at the dosage of $100 \mathrm{mg} \cdot \mathrm{kg}^{-1}$ phosphorus in the soil there was a statistically significant reduction to this variable for the soybean cultivar MSoy 9144RR. At the dosages of 50 and $200 \mathrm{mg} \cdot \mathrm{kg}^{-1}$ phosphorus, for the $\mathrm{cv}$. MSoy 8527RR, such reduction was also observed for the seeds sorted by the screen 14 , with perforations of $5.5 \mathrm{~mm}$ in diameter. This event indicates that larger size soybean seeds possess the genetic trait of also producing larger seeds when the level of phosphorus in the soil is adequate. At the dosage of $50 \mathrm{mg} . \mathrm{kg}^{-1}$ phosphorus in the soil there was an increment of $27.25 \%$ and $29.66 \%$ on the total mass of seeds per plant for the cultivars MSoy 9144RR and MSoy 8527RR, respectively.

Table 8. Mean values obtained for the total mass of seeds per plant $(\mathrm{g})$, produced by soybean plants, originating from seeds of two soybean cultivars, classified by screens with two perforation sizes, and grown into plastic pots containing soil with different dosages of phosphorus $(\mathrm{P})$, under greenhouse environmental conditions.

\begin{tabular}{|c|c|c|c|c|c|}
\hline \multirow{3}{*}{$\begin{array}{l}\text { Perforation } \\
\text { diameter }\end{array}$} & \multicolumn{5}{|c|}{ Dosage of $\mathrm{P}$ in the soil $\left(\mathrm{mg} \cdot \mathrm{kg}^{-1}\right)$} \\
\hline & 50 & 100 & 200 & 300 & 400 \\
\hline & \multicolumn{5}{|c|}{ Cv. MSoy 9144RR } \\
\hline $5.5 \mathrm{~mm}$ & $4.11 \mathrm{a}^{*}$ & $6.29 \mathrm{~b}$ & $9.66 \mathrm{a}$ & $15.50 \mathrm{a}$ & $17.66 \mathrm{a}$ \\
\hline $7.5 \mathrm{~mm}$ & $5.23 \mathrm{a}$ & $7.64 \mathrm{a}$ & $10.59 \mathrm{a}$ & $15.52 \mathrm{a}$ & $17.56 \mathrm{a}$ \\
\hline CV (\%) & \multicolumn{5}{|c|}{9.52} \\
\hline $\begin{array}{l}\text { Perforation } \\
\text { diameter }\end{array}$ & \multicolumn{5}{|c|}{ Cv. MSoy 8527RR } \\
\hline $5.5 \mathrm{~mm}$ & $4.19 \mathrm{~b}$ & $7.80 \mathrm{a}$ & $9.59 \mathrm{~b}$ & $16.01 \mathrm{a}$ & $18.79 \mathrm{a}$ \\
\hline $7.5 \mathrm{~mm}$ & $5.42 \mathrm{a}$ & $8.16 \mathrm{a}$ & $10.90 \mathrm{a}$ & $16.04 \mathrm{a}$ & $18.98 \mathrm{a}$ \\
\hline CV $(\%)$ & \multicolumn{5}{|c|}{6.83} \\
\hline
\end{tabular}

*Means followed by the same letter, within each dose of $\mathrm{P}$, do not statistically differ between each other by $\mathrm{F}$ test $(\mathrm{P}<0.05)$; $\mathrm{CV}=$ Coefficient of variation.
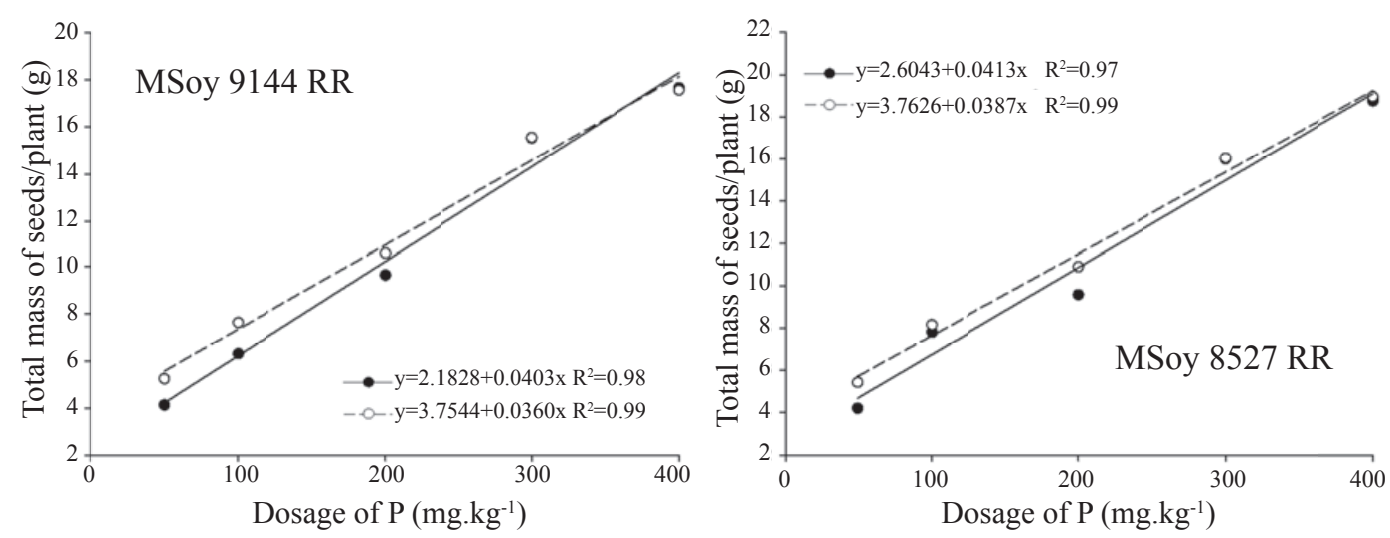

Figure 8. Graphical representation of the linear regression curves plotted with the mean values obtained for the total mass of seeds per plant $(\mathrm{g})$, produced by soybean plants originated from seeds of two soybean cultivars, classified by screens with two perforation sizes, and grown into plastic pots containing soil with different dosages of phosphorus (P), under greenhouse environmental conditions.

Within this same context, Morrison and Xue (2007), in a study performed with three different seed batches of three distinct soybean cultivars, with seeds classified by size into large, medium and small; and by using a lot of seeds nonclassified by size of each cultivar as control, have also found that the smaller seeds have produced soybean plants with lower yield, in two of the three cultivars assessed.

By assessing the influence of seed sizes $(4.0 \mathrm{~mm}, 5.0$ $\mathrm{mm}$ and $6.0 \mathrm{~mm}$ in diameter) and physiological quality of the seeds, on the initial growth of plants and on productivity of 
the soybean crop, Pádua et al. (2010) have also found that the smaller size seeds produced plants with lower height and lower productivity, as compared to plants originating from larger size seeds. Furthermore, these authors have also found statistically significant differences among the mean results obtained for the both cultivars and for the three seed sizes assessed, and that the plants originating from seeds with $4.0 \mathrm{~mm}$ in diameter have produced a mean of 2,500 kg.ha-1 of grains; while plants originating from seeds with $5.0 \mathrm{~mm}$ and $6.0 \mathrm{~mm}$ in diameter have produced a mean of 3,000 kg.ha- ${ }^{-1}$ and 3,500 kg.ha-1 of grains, respectively. Thereby, supporting the likelihood of that when the soybean seeding is performed with larger size seeds, the yield achieved will certainly be higher.

\section{Conclusions}

The size of soybean seeds do not significantly influence the yield components of the crop; however the larger seeds have the genetic trait for producing bigger and heavier seeds;

The increase on phosphorus levels in the soil induces to an equivalent positive linear increase of the soybean production components, such as: plant height, height the first pod insertion, number of nodes per plant, number of pods per plant, number of seeds per pod, and total number of seeds per plant.

\section{References}

ÁVILA, W.; PERIN, A.; GUARESCHI, R.F.; GAZOLLA, P.R. Influência do tamanho da semente na produtividade de variedades de soja. Revista Agrarian, v.1, n.2, p.83-89, 2008. http://www.periodicos.ufgd.edu.br/index. php/agrarian/article/download/257/209

BRASIL. Ministério da Agricultura, Pecuária e Abastecimento. Regras para análise de sementes. Ministério da Agricultura, Pecuária e Abastecimento. Secretaria Nacional de Defesa Agropecuária. Brasília: MAPA/ACS, 2009. 395p. http://www.agricultura.gov.br/arq_editor/file/2946regrasanalisesementes.pdf

CAMOZZATO, V.A.; PESKE, S.T.; POSSENTI, J.C.; MENDES, A.S. Desempenho de cultivares de soja em função do tamanho das sementes. Revista Brasileira de Sementes, v.31, n.1, p.288-292, 2009. http://www. scielo.br/pdf/rbs/v31n1/a32v31n1.pdf

CARVALHO, N.M.; NAKAGAWA, J. Sementes: ciência, tecnologia e produção. Jaboticabal: FUNEP, 2012. 5.ed. 590p.

DELWICHE, L.D.; SLAUGHTER, S.J. The Little SAS Book: a Primer. Cary: SAS Institute, 2003. 268p.

EMBRAPA. Empresa Brasileira de Pesquisa Agropecuária. Tecnologias de Produção de Soja - Região Central do Brasil 2012 e 2013. Londrina: EMBRAPA-CNPSo (Sistema de Produção, 15). 2011. 262p.

FINOTO, E.L.; CARREGA, W.C.; SEDIYAMA, T.; ALBUQUERQUE, J.A.A.; CECON, P.R.; REIS, M.S. Efeito da aplicação de fungicida sobre caracteres agronômicos e severidade das doenças de final de ciclo na cultura da soja.Agro@mbiente On-line, v.5, n.1, p.44-49, 2011. http://revista.ufrr.br/ index.php/agroambiente/article/view/418/432
FONSECA, N.R.; SÁ, M.E. Qualidade física e fisiológica da semente de dois cultivares de soja em função de doses de potássio e calcário. Acto Scientiarum. Agronomy, v.27, n.2, p.261-269, 2005. http://periodicos.uem.br/ ojs/index.php/ActaSciAgron/article/view/1844/1138

KOLCHINSKI, E.M.; SCHUCH, L.O.B.; PESKE, S.T. Crescimento inicial de soja em função do vigor das sementes. Revista Brasileira de Agrociência, v.12, n.2, p.163-166, 2006. http://www.ufpel.tche.br/faem/agrociencia/v12n2/artigo07.pdf

LIMA, A.M.M.P.; CARMONA, R. Influência do tamanho da semente no desempenho produtivo da soja. Revista Brasileira de Sementes, v.21, n.1, p.157163, 1999. http://www.abrates.org.br/revista/artigos/1999/v21n1/artigo24.pdf

MARCOS-FILHO, J. Fisiologia de sementes de plantas cultivadas. Piracicaba: FEALQ, 2005. 495p

MORRISON, M.J.; XUE, A.G. The influence of seed size on soybean yield in short-season regions. Canadian Journal of Plant Science, v.87, n.1, p.89-91, 2007. http://pubs.aic.ca/doi/abs/10.4141/P05-209

MUNIZZI, A.; BRACCINI.; A.L.; RANGEL, M.A.S.; SCAPIM; C.A.; ALBRECHT, L.P. Qualidade de sementes de quatro cultivares de soja, colhidas em dois locais no estado de Mato Grosso do Sul. Revista Brasileira de Sementes, v.32, n.1, p.176-185, 2010. http://www.scielo.br/pdf/rbs/v32n1/v32n1a20.pdf

NOVAIS, R.F.; NEVES, J.C.L.; BARROS, N.F. Ensaio em ambiente controlado. In: OLIVEIRA, A.J.; GARRIDO, W.E.; ARAUJO, J.D.; LOURENÇO, S. (Coord.). Métodos de pesquisa em fertilidade do solo. Brasília: Embrapa-SEA, 1991. p.189-253.

PÁDUA, G.P.; ZITO, R.K.; ARANTES, N.E.; FRANÇA-NETO, J.B Influência do tamanho da semente na qualidade fisiológica e na produtividade da cultura da soja. Revista Brasileira de Sementes, v.23, n.3, p.9-16, 2010. http://www.scielo.br/pdf/rbs/v32n3/v32n3a01.pdf

PERIN, A.; ARAUJO, A.P.; TEIXEIRA, M.G. Efeito do tamanho da semente na acumulação de biomassa e nutrientes e na produtividade do feijoeiro. Pesquisa Agropecuária Brasileira, v.37, n.12, p.1711-1718, 2002. http:// www.scielo.br/pdf/pab/v37n12/14637.pdf

PICCININ， G.G.; DAN, L.G.M.; RICCI， T.T.; BRACCINI， A.L.; BARBOSA, M.C.; MOREANO, T.B.; NETO, A.H.; BAZO, G.L. Relação entre o tamanho e a qualidade fisiológica e sanitária de sementes de soja Revista Agrarian, v.5, n.15, p.20-28, 2012. http://www.periodicos.ufgd.edu. br/index.php/agrarian/article/view/1186/1009

REZENDE，P.M.; MACHADO，J.D.C.; GRIS，C.F.; GOMES，L.L.; BOTREL, E.P. Efeito da semeadura a seco e tratamento de sementes, na emergência, rendimento de grãos e outras características da soja (Glycine $\max$ (L.) Merrill). Revista Ciência e Agrotecnologia, v.27, n.1, p.76-83, 2003. http://www.scielo.br/pdf/cagro/v27n1/a09v27n1.pdf

SANTOS, P.M.; REIS, M.S.; SEDIYAMA, T.; ARAÚJO, E.F.; CECON, P.R.; SANTOS, M.R. Efeito da classificação por tamanho da semente de soja na sua qualidade fisiológica durante o armazenamento. Acta Science Agronomy, v.27, n.3, p.395-402, 2005. http://periodicos.uem.br/ojs/index. php/ActaSciAgron/article/view/1398/814

SEDIYAMA, T. (Org.). Tecnologias de produção e usos da soja. Londrina, Paraná: Mecenas, 2009. 314p.

SCHEEREN, B.R.; PESKE, S.T.; SCHUCH, L.O.B.; BARROS, A.C.A. Qualidade fisiológica e produtividade de sementes de soja. Revista Brasileira de Sementes, v.32, n.3, p.35-41, 2010. http://www.scielo.br/pdf/rbs/v32n3/v32n3a04.pdf

VANCE, C.P.; UHDE-STONE, C.; ALLEN, D.L. Phosphorus acquisition and use: Critical adaptations by plants for securing a nonrenewable resource. New Phytologist, v.157, p.423-447, 2003. http://onlinelibrary.wiley.com/ doi/10.1046/j.1469-8137.2003.00695.x/full 